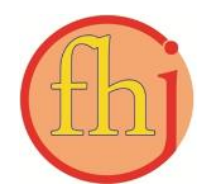

Faletehan Health Journal, 8 (2) (2021) 92-101

www. journal.Ippm-stikesfa.ac.id/ojs/index.php/FHJ

ISSN 2088-673X | e-ISSN 2597-8667

\title{
Analisis Asupan Zat Gizi Terhadap Status Gizi Balita
}

\author{
Yohana Riang Toby ${ }^{1}$, Lina Dewi Anggraeni ${ }^{1 *}$, Sada Rasmada ${ }^{1}$ \\ ${ }^{1}$ STIK Sint Carolus, Jakarta \\ *Corresponding Author: linadewiam@gmail.com
}

\begin{abstract}
Abstrak
Status gizi merupakan gambaran keadaan ketahanan pangan yang dibutuhkan oleh tubuh. Dampak yang akan ditimbulkan kedepannya akibat kejadian gizi buruk maupun gizi berlebih yang dialami anak bawah lima tahun sangat di khawatirkan. Tujuan penelitian ini adalah untuk mengetahui faktor - faktor yang berhubungan dengan status gizi balita di Pustu Oebufu Kecamatan Oebobo Kota Kupang pada bulan Februari tahun 2018. Jenis penelitian yang digunakan adalah observasional analitik dengan pendekatan cross-sectional. Populasi dalam penelitian ini adalah balita yang berada dalam cakupan pelayanan di wilayah kerja Pustu Oebufu. Teknik pengambilan sampel yang digunakan adalah purposive sampling dengan jumlah sampel sebanyak 136 ibu yang memiliki anak balita. Hasil penelitian menunjukkan terdapat $73,5 \%$ balita dengan status gizi normal. Hasil uji statistik menunjukkan terdapat hubungan antara pendidikan $(p=0,015)$, pengetahuan $(p=0,000)$ dan asupan makanan seperti asupan energi $(p=0.000)$, protein $(p=0.000)$, lemak $(p=0.000)$, karbohidrat $(p=0.000)$, vitamin $A(p=0.000)$, vitamin $C(p=0.000)$, kalsium $(p=0.002)$, besi $(p=0.000)$, dan zink $(p=0.000$ ) dengan status gizi ( $p$ value $<0.05$ ). Keterlibatan pengasuhan orang tua khususnya ibu berkaitan erat dengan status gizi balita. Ibu hendaknya memiliki pengetahuan yang baik mengenai asupan gizi bagi balita.
\end{abstract}

Kata Kunci: Asupan Zat Gizi, Karakteristik Ibu, Status Gizi, Balita

\section{Analysis of Nutrient Intake on Nutritional Status of Under Five Year Children}

\begin{abstract}
Nutritional status is a depiction of food security needed by the body. The impacts due to the incidence of malnutrition and overnutrition experienced by children under five years are worrying. The purpose of this study was to determine the factors associated with the nutritional status of under five year children in Pustu Oebufu, Oebobo Sub-District Kupang City in February 2018. The research type used was observational analytic with the cross-sectional design approach. The population were children under five years who were in the service coverage of Oebufu Pustu work area. The sampling technique was purposive and the sample size was 136 mothers who had a child under five. The study found $73.5 \%$ of under-five children had normal nutritional status. The statistical test results showed that there is a relationship between education ( $p=0.015)$, knowledge $(p=0.000)$, and food supply such as energy intake $(p=0.000)$, protein $(p=0.000)$, fat $(p=0.000)$, carbohydrate $(p=0.000)$, vitamin $A(p=0.000)$, vitamin $C(p=0.000)$, calcium $(p=0.002)$, iron $(p=0.000)$ and zink $(p=0.000)$ with nutritional status ( $p$-value $<0.05)$. Parent involvement, especially mothers, is closely related to the nutritional status of under five year children. Mothers should have good knowledge of nutrient intake for children under five.

Keywords: Nutrient Intake, Maternal Characteristics, Nutritional Status, Under Five Year Children
\end{abstract}


Faletehan Health Journal, 8 (2) (2021) 92-101

\section{Pendahuluan}

Salah satu tujuan dari program Sustainable Development Goals (SDGs) adalah hidup tanpa kelaparan dan kehidupan sehat dan sejahtera (Pemerintah Provinsi Banten, 2016). Kualitas hidup individu dapat dilihat dari kesehatannya. Gangguan kesehatan dapat terjadi pada semua usia, terutama lebih rentan pada balita karena sistem imun balita masih dalam proses perkembangan. Gangguan kesehatan yang sering terjadi di dunia adalah terjadinya masalah gizi baik gizi kurus maupun gemuk. Menurut World Health Organization (WHO) 2016 terdapat 50 juta anak kurus dan 41 juta anak gemuk dunia dari 667 juta anak di seluruh (Badan Penelitian dan Pengembangan Kesehatan Kementerian Kesehatan RI, 2013).

Pengukuran atropometri dengan mengunakan indeks berat badan menurut tinggi badan $(\mathrm{BB} / \mathrm{TB})$ atau berat badan menurut panjang badan (BB/PB) merupakan salah satu cara untuk menentukan status gizi individu. Indeks $\mathrm{BB} / \mathrm{TB}$ atau $\mathrm{BB} / \mathrm{PB}$ diklasifikasi menjadi gemuk (obesity), gemuk (overweight), normal, kurus (wasted) dan sangat kurus (served wasted) (Kementerian Kesehatan Republik Indonesia, 2010). Menurut Riset Kesehatan Dasar (Rikesdas) pada tahun 2013, berdasarkan indeks BB/TB terjadi penurunan 0,9 persen prevalensi sangat kurus, 0,6 persen prevalensi kurus dan 0,3 persen prevalensi gemuk dari tahun 2007 ke 2013 (Badan Penelitian dan Pengembangan Kesehatan Kementerian Kesehatan RI, 2013).

Menurut Dinas Kesehatan NTT tahun 2015, beberapa daerah di NTT yang memiliki lebih dari 200 kasus gizi buruk yaitu di daerah Kota Kupang, Kabupaten Kupang, TTS, Alor, Sumba Barat Daya dan Sumba Timur. Lalu di daerah Nagakeo, Ngada dan Sumba Tengah angka kejadian gizi buruk $<50$ kasus (Dinas Kesehatan Nusa Tenggara Timur, 2015). Keadaan ini meningkat pada tahun 2016 terdapat 278 kasus gizi buruk di Kota kupang, sedangkan awal tahun 2017 sampai dengan bulan Februari tahun 2017 kemarin tercatat 46 balita yang menderita gizi buruk (Pos Kupang, 2017) Berdasarkan data Dinas Kesehatan Kota Kupang tahun 2015 tercatat 94 balita gizi buruk yang mendapatkan perawatan di puskesmas yang berada diwilayah Oebobo. Angka kejadian gizi buruk pada balita pada awal tahun 2017 sampai dengan bulan Maret tahun 2017 terdapat 59 balita di
Puskesmas Oepoi (Dinas Kesehatan Nusa Tenggara Timur, 2015).

Dampak yang akan ditimbulkan kedepannya akibat kejadian gizi buruk yang dialami balita sangat dikhawatirkan. Bukan hanya masalah pertumbuhannya yang akan terhambat, tapi juga dapat menyebabkan balita kekurangan tenaga untuk beraktivitas, pertahan tubuh balita juga akan bermasalah dan tidak terjadinya perkembangan fungsi otak (Par'i, 2016). Ada juga dampak yang disebabkan oleh gizi berlebih yaitu terjadinya resiko obesitas maupun penyakit degeneratif yang akan timbul nanti (Sudargo, Rosiyani, \& Kusmayanti, 2014). Oleh karena itu, menjaga status gizi balita sangat penting.

Menjaga status gizi balita tersebut diperlukan pengetahuan ibu yang baik karena pengetahuan ibu mengenai makanan yang baik untuk dikonsumsi balita akan mempengaruhi status gizi balita menjadi baik. Pendidikan seorang ibu dapat mempengaruhi pengetahuan ibu. Makin tinggi pendidikan ibu diharapkan pengetahuan gizi ibu mengenai asupan zat gizi semakin baik. Asupan zat gizi merupakan salah satu faktor yang berhubungan dengan status gizi balita. Asupan zat gizi dapat diperoleh dari zat gizi makro dan mikro. Selain itu faktor-faktor yang mempengaruhi status gizi balita adalah pemberian ASI secara ekslusif, pola asuh balita serta pekerjaan ibu.

Perkawinan dini untuk anak usia sekolah saat ini menjadi suatu fenomena tersendiri di Kota Kupang yang menyebabkan pendidikan anak menjadi terputus sehingga tidak dapat melangkahkan ke jenjang yang lebih tinggi sehingga pengetahuannya juga terbatas (Pos Kupang, 2016) Selain itu, berdasarkan hasil wawancara masih terdapat pandangan masyarakat bahwa wanita tidak perlu sekolah yang tinggi karena nanti juga akan kerja di dapur. Beberapa kepala keluarga juga melarang ibu untuk bekerja karena pencari nafkah adalah suami. Namun, masih banyak keluarga yang mempunyai perekonomian yang rendah menyebabkan pemenuhan bahan pangan sulit didapatkan. Berdasarkan hasil wawancara beberapa ibu juga menggatakan bahwa salah satu cara untuk mengatasi masalah kebutuhan pangan tersebut pemerintah membuat program Kelompok Wanita Tani (KWT) untuk dapat mengelola hasil tersebut untuk kebutuhan sendiri maupun untuk dijual. Ada juga ibu yang bekerja untuk membatu perekonomian keluarga. Ibu yang 
bekerja biasanya setelah masa cuti selesai bayi akan diberikan makanan pendamping sebelum usianya 6 bulan (Pos Kupang, 2015). Hal tersebut berdampak pada pemberian ASI menjadi tidak ekslusif lagi. Penelitian ini bertujuan untuk mengetahui faktor-faktor yang berhubungan dengan status gizi balita.

\section{Metodologi Penelitian}

Penelitian ini mengunakan desain penelitian potong lintang (cross sectional) dengan populasi sebanyak 208 balita dan sampel sebanyak 136 balita dan ibu. Teknik pengambilan sampel yang digunakan dalam penelitian ini adalah mengunakan nonprobability sampling dengan cara purposive sampling. Metode penelitian yang digunakan adalah pendekatan kuantitatif. Kriteria inklusi yang digunakan adalah Ibu yang mempunyai balita yang berusia $1-5$ tahun, bila ibu mempunyai dua atau lebih balita maka pilih yang termuda dan Ibu yang bisa membaca dan menulis.

Penelitian ini dilakukan di empat posyandu di wilayah kerja Puskesmas Pembantu (Pustu) Oebufu pada bulan Februari 2018. Penelitian ini mengunakan timbangan dacin, meteran untuk mengukur tinggi/panjang badan balita, kuesioner pengetahuan ibu dan fomulir food recall. Kuesioner pengetahuan ibu disesuaikan dengan Pedoman Gizi Seimbang (PGS) dan praktiknya dalam kehidupan sehari-hari, serta telah melalui uji validitas dan reliabilitas dengan Chonbrach's Alpha 0.650. Untuk asupan makan balita dikelompokkan menjadi 1) zat gizi makro, cukup jika $\geq 77 \%$ AKG dan tidak cukup jika $<77 \%$ AKG; 2) zat gizi mikro, cukup jika $\geq$ nilai EAR dan tidak cukup jika <nilai EAR. Analisis yang digunakan untuk membandingkan dua variabel dengan data ordinal maupun nominal dan dalam jumlah sampel yang besar menggunakan uji chi-square (Gani \& Amalia, 2015). Penelitian ini mendapatkan ijin penelitian dari Pemerintah Kota Kupang Kecamatan Oebobo dengan nomor KEC.OF.B.070/126/01/2017.

\section{Hasil dan Pembahasan}

Pada Tabel 1 berdasarkan indikator BB/TB atau $\mathrm{BB} / \mathrm{PB}$ yang digunakan terlihat bahwa $73.5 \%$ balita memiliki status gizi normal. Selanjutnya status gizi akan dibagi menjadi normal dan tidak normal. Status gizi tidak normal terdiri dari balita dengan status gizi kurus dan gemuk.
Tabel 2 menunjukkan karakteristik ibu yang meliputi 50.0\% ibu memiliki pendidikan SMA dan $20,6 \%$ berpendidikan SMP. Selanjutnya untuk variabel pendidikan ibu akan dibagi menjadi pendidikan rendah (SD dan SMP) dan pendidikan tinggi (SMA dan Perguruan Tinggi (PT)). 83.1\% ibu tidak bekerja, $50.0 \%$ ibu mempunyai pengetahuan baik, dan $79.4 \%$ ibu memberikan ASI eksklusif.

Gambaran asupan gizi dari balita dapat dilihat pada Tabel 3 dimana terdiri dari asupan energi, protein, lemak, karbohidrat, vitamin A, vitamin C, kalsium, besi dan zink. Dari 136 balita, 66.9\% memiliki asupan energi cukup, $89.0 \%$ memiliki asupan protein cukup, $58.1 \%$ memiliki asupan lemak cukup, $63.2 \%$ memiliki asupan karbohidrat cukup, $75.7 \%$ memiliki asupan vitamin A cukup, 50.7\% memiliki asupan vitamin C cukup, $72.8 \%$ memiliki asupan kalsium cukup, $61.0 \%$ memiliki asupan besi cukup dan 59.6\% memiliki asupan zink yang tidak cukup.

Tabel 1: Distribusi Status Gizi Balita

\begin{tabular}{lcc}
\hline \multicolumn{1}{c}{ Status Gizi } & N & \% \\
\hline Kurus & 31 & 22.8 \\
\hline Normal & 100 & 73.5 \\
\hline Gemuk & 5 & 3.7 \\
\hline
\end{tabular}

Tabel 2: Karakteristik Ibu

\begin{tabular}{lcc}
\hline Karakteristik Ibu & N & \% \\
\hline Pendidikan Ibu & & \\
Tidak Sekolah & 1 & 0.7 \\
SD & 24 & 17.6 \\
SMP & 28 & 20.6 \\
SMA & 68 & 50.0 \\
PT & 15 & 11.0 \\
\hline Pekerjaan Ibu & & \\
Tidak bekerja & 113 & 83.1 \\
Bekerja & 23 & 16.9 \\
\hline Pengetahuan & & \\
Kurang & 10 & 7.4 \\
Cukup & 58 & 42.6 \\
Baik & 68 & 50.0 \\
\hline Pemberian ASI Eksklusif & & \\
Tidak & 28 & 20.6 \\
Ya & 108 & 79.4 \\
\hline
\end{tabular}


Faletehan Health Journal, 8 (2) (2021) 92-101 www. journal.Ippm-stikesfa.ac.id/ojs/index.php/FHJ ISSN 2088-673X | 2597-8667

Tabel 3: Kategori Asupan Makanan Balita

\begin{tabular}{lcc}
\hline Asupan Makan Balita & N & \% \\
\hline Asupan Energi & & \\
Tidak Cukup & 45 & 33.1 \\
Cukup & 91 & 66.9 \\
\hline Asupan Protein & & \\
Tidak Cukup & 15 & 11.0 \\
Cukup & 121 & 89.0 \\
\hline Asupan Lemak & & \\
$\quad$ Tidak Cukup & 57 & 41.9 \\
Cukup & 79 & 58.1 \\
\hline Asupan Karbohidrat & & \\
Tidak Cukup & 50 & 36.8 \\
Cukup & 86 & 63.2 \\
\hline Asupan Vit. A & & \\
Tidak Cukup & 33 & 24.3 \\
Cukup & 103 & 75.7 \\
\hline Asupan Vit. C & & \\
Tidak Cukup & 67 & 49.3 \\
Cukup & 69 & 50.7 \\
\hline Asupan Kalsium & & \\
Tidak Cukup & 37 & 27.2 \\
Cukup & 99 & 72.8 \\
\hline Asupan Besi & & \\
Tidak Cukup & 53 & 39.0 \\
Cukup & 83 & 61.0 \\
\hline Asupan Zink & & \\
Tidak Cukup & 81 & 59.6 \\
Cukup & 55 & 40.4 \\
\hline
\end{tabular}

Pada tabel 4 menunjukkan bahwa pada penelitian ini terdapat hubungan antara pendidikan ibu $(\mathrm{p}=0.015)$ dan pengetahuan ibu $(\mathrm{p}=0.000)$ dengan status gizi balita. Namun, pekerjaan ibu $(\mathrm{p}=0.279)$ dan pemberian ASI eksklusif $(\mathrm{p}=0.085)$ tidak memiliki hubungan yang bermakna dengan status gizi balita.

Tabel 5 menunjukkan Hubungan antara asupan makanan dengan status gizi balita. Pada penelitian ini menunjukkan bahwa terdapat hubungan antara asupan energi $(\mathrm{p}=0.000)$, asupan protein $(\mathrm{p}=0.000)$, asupan lemak ( $\mathrm{p}=0.000)$, asupan karbohidrat $\quad(\mathrm{p}=0.000)$, asupan vitamin A $(\mathrm{p}=0.000)$, asupan vitamin $\mathrm{C}(\mathrm{p}=0.000)$, asupan kalsium $(\mathrm{p}=0.002)$, asupan besi $(\mathrm{p}=0.000)$ dan asupan zink ( $\mathrm{p}=0.000)$ dengan status gizi balita.

\section{Hubungan Pendidikan Ibu dengan Status Gizi Balita}

Berdasarkan hasil analisis diketahui terdapat hubungan bermakna antara tingkat pendidikan ibu dengan status gizi balita di wilayah kerja Pustu Oebufu. Hasil penelitian ini sejalan dengan penelitian Suryani (2017) serta Khotimah dan Kuswandi (2014) menunjukkan adanya hubungan yang bermakna antara pendidikan ibu dengan status gizi balita. Hasil penelitian ini bertentangan dengan hasil penelitian Ziliwu, Anggraeni, dan Lina (2020) yang menunjukkan tidak terdapat hubungan antara pendidikan ibu dengan status gizi balita.

Hasil penelitian ini sejalan dengan pendapat Wiku (2010) yaitu semakin tinggi tingkat pendidikan ibu maka semakin baik juga tingkat ketahanan pangan keluarga yang akan mempengaruhi status gizi balita. Menurut Andriani dan Bambang (2012), segala informasi yang ada terutama tentang cara pengasuhan anak yang baik dapat diterapkan bila ibu memiliki pendidikan yang baik juga sehingga ibu dapat menyediakan menu makanan sesuai kebutuhan keluarga terutama anak sehingga dapat meningkatkan kualitas dan kuantitas pangan yang akan dikonsumsi responden.

Semakin tinggi pendidikan ibu semakin memudahkan ibu dalam menyerap informasi dan menerapkannya dalam hidup sehari-hari. Hal tersebut dapat meningkatkan ketanggapan ibu dalam mengambil keputusan bila terjadi masalah gizi dalam keluarga.

\section{Hubungan Pekerjaan Ibu dengan Status Gizi Balita}

Berdasarkan hasil analisis tidak ada hubungan bermakna antara pekerjaan ibu dengan status gizi balita di wilayah kerja Pustu Oebufu. Pada penelitian Jayarni dan Surmami (2018) mendukung penelitian ini bahwa tidak ada hubungan antara pekerjaan ibu dengan status gizi balita. Namun, hasil penelitian ini bertentangan dengan hasil penelitian Putri dkk (2015) yang menunjukkan adanya hubungan antara pekerjaan ibu dan status gizi balita.

Hasil ini bertantangan dengan pendapat Wawan dan Dewi (2011) yang menyatakan bahwa kehidupan keluarga akan sangat dipengaruhi oleh pekerjaan ibu. Ibu yang pergi bekerja biasanya menghabiskan banyak waktu diluar sehingga besar resiko balita menjadi kurang diperhatikan padahal balita masih belum dapat memenuhi kebutuhannya sendiri sehingga harus didampingi dan diperhatikan terutama pemberian kebutuhan asupan makanan bagi balita. 
Tabel 4: Hubungan antara Kategori ibu terhadap Status Gizi Balita

\begin{tabular}{|c|c|c|c|c|c|c|c|}
\hline \multirow{3}{*}{ Kategori } & \multicolumn{5}{|c|}{ Status Gizi } & \multirow{3}{*}{$\begin{array}{c}\text { Total } \\
\%\end{array}$} & \multirow{3}{*}{$p$ value } \\
\hline & \multicolumn{2}{|c|}{ Tidak Normal } & \multicolumn{3}{|c|}{ Normal } & & \\
\hline & $\mathrm{N}$ & $\%$ & $\mathrm{~N}$ & $\%$ & $\mathrm{~N}$ & & \\
\hline \multicolumn{8}{|l|}{ Pendidikan Ibu } \\
\hline Pendidikan rendah & 20 & 37.7 & 33 & 62.3 & 53 & 100.0 & \multirow{2}{*}{$0.015^{*}$} \\
\hline Pendidikan tinggi & 16 & 19.3 & 67 & 80.7 & 83 & 100.0 & \\
\hline \multicolumn{8}{|l|}{ Pekerjaan Ibu } \\
\hline Tdk Bekerja & 32 & 28.3 & 81 & 71.7 & 113 & 100.0 & \multirow{2}{*}{0.279} \\
\hline Bekerja & 4 & 17.4 & 19 & 82.6 & 23 & 100.0 & \\
\hline \multicolumn{8}{|l|}{ Pengetahuan Ibu } \\
\hline Kurang & 10 & 100 & 0 & 0.0 & 10 & 100.0 & \multirow{3}{*}{$0.000 *$} \\
\hline Cukup & 16 & 27.6 & 42 & 72.4 & 58 & 100.0 & \\
\hline Baik & 10 & 14.7 & 58 & 85.3 & 68 & 100.0 & \\
\hline \multicolumn{8}{|c|}{ Pemberian ASI Ekslusif } \\
\hline Tidak & 11 & 39.3 & 17 & 60.7 & 28 & 100.0 & \multirow{2}{*}{0.085} \\
\hline $\mathrm{Ya}$ & 25 & 23.1 & 83 & 76.9 & 108 & 100.0 & \\
\hline
\end{tabular}

Sumber: data primer yang diolah dengan program pengelolahan stastistik

Ket : $*$ p-value $<0.05$

Tabel 5: Hubungan antara Asupan Makanan terhadap Status Gizi Balita

\begin{tabular}{|c|c|c|c|c|c|c|c|}
\hline \multirow{3}{*}{ Kategori Asupan } & \multicolumn{4}{|c|}{ Status Gizi } & \multirow{2}{*}{\multicolumn{2}{|c|}{ Total }} & \multirow{3}{*}{ p value } \\
\hline & \multicolumn{2}{|c|}{ Tidak Normal } & \multicolumn{2}{|c|}{ Normal } & & & \\
\hline & $\mathrm{N}$ & $\%$ & $\mathrm{~N}$ & $\%$ & $\mathrm{~N}$ & $\%$ & \\
\hline \multicolumn{8}{|l|}{ Asupan Energi } \\
\hline Tidak Cukup & 24 & 53.3 & 21 & 46.7 & 45 & 100.0 & \multirow{2}{*}{$0.000^{*}$} \\
\hline Cukup & 12 & 13.2 & 79 & 86.8 & 91 & 100.0 & \\
\hline \multicolumn{8}{|l|}{ Asupan Protein } \\
\hline Tidak Cukup & 10 & 66.7 & 5 & 33.3 & 15 & 100.0 & \multirow{2}{*}{$0.000 *$} \\
\hline Cukup & 26 & 21.5 & 95 & 78.5 & 121 & 100.0 & \\
\hline \multicolumn{8}{|l|}{ Asupan Lemak } \\
\hline Tidak Cukup & 24 & 42.1 & 33 & 57.9 & 57 & 100.0 & \multirow[b]{2}{*}{$0.000 *$} \\
\hline Cukup & 12 & 15.2 & 67 & 84.8 & 79 & 100.0 & \\
\hline \multicolumn{8}{|l|}{ Asupan Karbohidrat } \\
\hline Tidak Cukup & 26 & 52.0 & 24 & 48.0 & 50 & 100.0 & \multirow{2}{*}{$0.000^{*}$} \\
\hline Cukup & 10 & 11.6 & 76 & 88.4 & 86 & 100.0 & \\
\hline \multicolumn{8}{|l|}{ Asupan Vitamin A } \\
\hline Tidak Cukup & 20 & 60.6 & 13 & 39.4 & 33 & 100.0 & \multirow{2}{*}{$0.000 *$} \\
\hline Cukup & 16 & 15.5 & 87 & 84.5 & 103 & 100.0 & \\
\hline \multicolumn{8}{|l|}{ Asupan Vitamin C } \\
\hline Tidak Cukup & 28 & 41.8 & 39 & 58.2 & 67 & 100.0 & \multirow[b]{2}{*}{$0.000 *$} \\
\hline Cukup & 8 & 11.6 & 61 & 88.4 & 69 & 100.0 & \\
\hline \multicolumn{8}{|l|}{ Asupan Kalsium } \\
\hline Tidak Cukup & 17 & 45.9 & 20 & 54.1 & 37 & 100.0 & \multirow{2}{*}{$0.002 *$} \\
\hline Cukup & 19 & 19.2 & 80 & 80.8 & 99 & 100.0 & \\
\hline \multicolumn{8}{|l|}{ Asupan Besi } \\
\hline Tidak Cukup & 23 & 43.4 & 30 & 56.6 & 53 & 100.0 & \multirow{2}{*}{$0.000 *$} \\
\hline Cukup & 13 & 15.7 & 70 & 84.3 & 83 & 100.0 & \\
\hline \multicolumn{8}{|l|}{ Asupan Zink } \\
\hline Tidak Cukup & 32 & 39.5 & 49 & 60.5 & 81 & 100.0 & \multirow{2}{*}{$0.000 *$} \\
\hline Cukup & 4 & 7.3 & 51 & 92.7 & 55 & 100.0 & \\
\hline
\end{tabular}

Sumber: data primer yang diolah dengan program pengelolahan stastistik

Ket : * p-value $<0.05$ 
Faletehan Health Journal, 8 (2) (2021) 92-101

\section{Hubungan Pengetahuan Ibu dengan Status Gizi Balita}

Berdasarkan hasil analisis diketahui terdapat hubungan bermakna antara pengetahuan ibu dengan status gizi balita di wilayah kerja Pustu Oebufu. Hasil penelitian ini sejalan dengan penelitian Baculu (2017) menyatakan ada hubungan antara pengetahuan ibu dan status gizi balita, ibu yang memiliki pengetahuan yang bervariasi dalam menyiapkan makan bagi anak maka semakin baik pula status gizi balita. Ibu dengan pengetahuan kurang juga akan berkurang pula status gizi balita. Pada penelitian Kalsum dan Gandini (2016) bertentangan dengan hal tersebut karena pada hasil penelitian tersebut menyatakan tidak ada hubungan antara pengetahuan ibu dengan status gizi balita.

Sesuai dengan pendapat Andriani dan Bambang (2012) dimana dengan pengetahuan kurang tentang gizi maupun kurang mampu ibu dalam menerapkan informasi tersebut dalam kehidupan sehari - sehari dapat mempengaruhi intake asupan gizi. Kurang mampu menerapkan informasi tersebut seperti membersihkan bahan makanan secara berlebihan atau memasak sayur agak lama dapat merusak dan menghilangkan nilai gizi yang terkandung dalam bahan makanan tersebut.

\section{Hubungan Pemberian ASI eksklusif dengan Status Gizi Balita}

Berdasarkan hasil analisis diketahui tidak ada hubungan bermakna antara pemberian ASI eksklusif dengan status gizi balita di wilayah kerja Pustu Oebufu. Penelitian ini didukung oleh penelitian Desfita dan Priwahyuni (2014) dan Nilakesuma dkk (2015). Berdasarkan kedua hasil penelitian tersebut menunjukkan bahwa tidak terdapat hubungan yang bermakna antara pemberian ASI ekslusif dengan status gizi balita. Namun, bertentangan dengan penelitian Oktavianis (2016) yang menunjukkan adanya hubungan antara pemberian ASI eksklusif dengan status gizi balita.

Hasil penelitian ini bertentangan dengan pendapat Andriani dan Wijatmadi (2012) yang mengatakan bahwa pemberian ASI eksklusif merupakan makanan terbaik untuk memenuhi kebutuhan gizi dalam 6 bulan pertama sehingga dengan pemberian ASI eksklusif status gizi balitanya juga akan baik. Menurut Arif (2009) ASI dapat disebut sebagai makanan satu - satunya bagi bayi selama 6 bulan pertama kehidupan. Setelah itu, ASI tetap diberikan didampingi dengan MPASI hingga usia 2 tahun.

\section{Hubungan Asupan Energi dengan Status Gizi Balita}

Berdasarkan hasil analisis diketahui terdapat hubungan bermakna antara asupan energi dengan status gizi balita di wilayah kerja Pustu Oebufu.

Penelitian Oktavia dkk (2017) dan Helmi (2013) menunjukkan adanya hubungan yang bermakna antara asupan energi dengan status gizi balita. Hasil penelitian ini sejalan dengan pemikiran Wijayanti (2017) dimana dengan kecukupan asupan energi sesuai dengan kebutuhan dan aktifitas yang dilakukan maka dapat mempertahankan berat badan sehingga status gizinya juga ikut terjaga dan mencegah terjadinya masalah gangguan gizi.

\section{Hubungan Asupan Protein dengan Status Gizi Balita}

Berdasarkan hasil analisis diketahui terdapat hubungan bermakna antara asupan protein dengan status gizi balita di wilayah kerja Pustu Oebufu.

Pada penelitian Astutik dkk (2018) dan Sari dkk (2016) menunjukkan adanya hubungan bermakna antara asupan protein dengan status gizi balita. Begitupun dengan penelitian Regar dan Sekartini (2013) juga menunjukkan hubungan yang bermakna antara asupan protein dengan status gizi. Hal ini bertentangan dengan penelitian Adani dkk (2016) yang menunjukkan bahwa tidak ada hubungan yang bermakna antara asupan protein dengan status gizi.

Hal ini juga sejalan dengan pemikiran Williams dan Wilkins (2011), dimana mereka mengatakan protein mempunyai fungsi utama sebagai zat pembangun, pemeliharaan struktur dan jaringan tubuh serta sebagai salah satu sumber energi. Dilihat fungsinya saja sudah diketahui pentingnya protein bagi tubuh anak selama masa pertumbuhan.

\section{Hubungan Asupan Lemak dengan Status Gizi Balita}

Berdasarkan hasil analisis diketahui terdapat hubungan bermakna antara asupan lemak dengan status gizi balita di wilayah kerja Pustu Oebufu. 
Pada penelitian Diniyyah dan Nindya (2017) dan Helmi (2013) menunjukkan adanya hubungan antara asupan lemak dengan status gizi balita. Hal ini tidak sejalan dengan penelitian Puspasari dan Andriani (2017) dan Adani dkk (2016) dimana asupan lemak tidak ada hubungan dengan status gizi balita.

Penelitian ini sejalan dengan pendapat Hardinsyah dan Supariasa (2016) yang berpendapat dengan mengonsumsi lemak dapat mencegah terjadinya penyakit menular maupun tidak menular terutama masalah gizi. Hal ini disebabkan karena lemak berfungsi sebagai sumber penganti energi ketika beraktifitas, sebagai pelumas pada jaringan, pemasok asam lemak esensial, penyerap vitamin larut lemak, melindungi organ dalam dan mengatur suhu tubuh.

\section{Hubungan Asupan Karbohidrat dengan Status Gizi Balita}

Berdasarkan hasil analisis diketahui terdapat hubungan bermakna antara asupan karbohidrat dengan status gizi balita di wilayah kerja Pustu Oebufu.

Pada penelitian Puspasari dan Adriani (2017) menunjukkan adanya hubungan asupan karbohidrat dengan status gizi balita. Penelitian yang dilakukan Baculu (2017) juga mendapatkan hasil adanya hubungan antara asupan karbohidrat dengan status gizi balita. Hal tersebut tidak sejalan dengan penelitian Regar dan Sekartini (2013) yang menyatakan bahwa tidak adanya hubungan yang bermakna antara asupan karbohidrat dengan status gizi.

Hal ini didukung oleh Williams dan Wilkins (2011) dimana asupan karbohidrat merupakan salah satu sumber energi yang paling mudah untuk dicari dan didapatkan. Karbohidrat juga berfungsi sebagai pemasok energi bagi otak dan saraf, pengendali metabolisme lemak, penyimpan glikogen dan pengendali peristaltik usus.

\section{Hubungan Asupan Vitamin A dengan Status Gizi Balita}

Berdasarkan hasil analisis diketahui terdapat hubungan bermakna antara asupan vitamin A dengan status gizi balita di wilayah kerja Pustu Oebufu.

Hasil ini sejalan dengan penelitian Sealey dan AC (2014) yang menyatakan tentang adanya hubungan antara asupan vitamin A dengan status gizi balita. Pada penelitian Rismiati (2016) juga mendukung adanya hubungan antara asupan vitamin A dengan status gizi balita. Namun bertentangan dengan penelitian Arnisam dkk (2013) yang menunjukkan tidak terdapat hubungan bermakna antara asupan vitamin A dengan status gizi balita.

Hal ini sejalan dengan pendapat Williams \& Wilkins (2011) yang mengatakan bahwa selain memiiki fungsi penting pada fungsi mata, vitamin A juga memiliki fungsi dalam pertumbuhan dan perkembangan jaringan dan fungsi imun tubuh. Kekurangan vitamin A merupakan salah satu faktor risiko terjadi infeksi campak yang parah pada balita dan membuat perubahan pada tekstur kulit yang bila berkepanjangan dapat mempengaruhi penurunan berat badan.

\section{Hubungan Asupan Vitamin C dengan Status Gizi Balita}

Berdasarkan hasil analisis diketahui terdapat hubungan bermakna antara asupan vitamin C dengan status gizi balita di wilayah kerja Pustu Oebufu.

Hal ini sejalan dengan penelitian Sealey dan AC (2014) tentang adanya hubungan antara asupan vitamin $\mathrm{C}$ dengan status gizi balita. Penelitian ini sejalan dengan pemikiran Sharlin dan Edelstein (2014) yang menggatakan vitamin $\mathrm{C}$ berperan dalam pertumbuhan dan perbaikan jaringan selain sebagai antioksidan.

\section{Hubungan Asupan Kalsium dengan Status Gizi Balita}

Berdasarkan hasil analisis diketahui terdapat hubungan bermakna antara asupan kalsium dengan status gizi balita di wilayah kerja Pustu Oebufu.

Pada penelitian Sari dkk (2016) dan Pramana (2018) menyatakan terdapat hubungan bermakna antara asupan kalsium dengan Status gizi. Hal ini bertentangan dengan penelitian Astutik dkk (2018) yang menyatakan bahwa tidak ada hubungan antara asupan kalsium dengan status gizi balita. Penelitian ini sesuai dengan pemikiran Sharlin dan Edelstein (2014) yang mengatakan bahwa kalsium memiliki banyak fungsi bagi tubuh manusia yaitu, sebagai pembentukan tulang dan gigi, menjaga kekebalan tubuh dan dapat memproduksi energi. 
Faletehan Health Journal, 8 (2) (2021) 92-101

\section{Hubungan Asupan Besi dengan Status Gizi Balita}

Berdasarkan hasil analisis diketahui terdapat hubungan bermakna antara asupan besi dengan status gizi balita di wilayah kerja Pustu Oebufu.

Pada penelitian Losong dan Adriani (2017) dan Dewi dan Nindya (2017) menunjukkan bahwa terdapat hubungan antara asupan besi dengan status gizi balita. Hal ini sejalan juga dengan penelitian Pramana (2018) tentang adanya hubungan antara asupan besi dengan status gizi balita.

Sesuai dengan pendapat Sharlin dan Edelstein (2014) mengatakan bahwa besi memiliki peran penting dalam pertumbuhan dan perkembangan jaringan. Hal ini karena besi berperan penting dalam pengikatan oksigen bersama hemoglobin, menghasilkan energi, fungsi imun dan perkembangan otak. Ketidakcukupan asupan besi akan mempengaruhi jumlah hemoglobinnya yang nantinya ikut menurun sehingga dapat terjadi anemia besi dan sistem imun pun akan menurun menyebabkan responden lebih mudah terkena penyakit.

\section{Hubungan Asupan Zink dengan Status Gizi Balita}

Berdasarkan hasil analisis diketahui terdapat hubungan bermakna antara asupan zink dengan status gizi balita di wilayah kerja Pustu Oebufu.

Pada penelitian Astutik dkk (2018) dan Losong dan Adriani (2017) menunjukkan hasil bahwa terdapat antara asupan zink dengan status gizi. Dewi dan Nindya (2017) juga mendukung bahwa asupan zink memiliki hubungan bermakna dengan status gizi balita. Hal ini tidak sejalan dengan penelitian Aridiyah dkk (2015) karena hasilnya menunjukkan tidak ada hubungan antara asupan zink dengan status gizi balita.

Dalam buku Hardinsyah dan Supariasa (2016) menunjukkan pernyataan yang sama yaitu zink berperan penting dalam pertumbuhan dan perkembangan selain itu juga zink berperan dalam menjaga sistem imun tubuh, fungsi neurologis dan reproduksi.

\section{Simpulan}

Pendidikan ibu, pengetahuan ibu dan asupan makanan merupakan faktor-faktor yang berhubungan dengan status gizi balita di Puskesmas Pembantu Oebufu. Keterlibatan pengasuhan orang tua khususnya ibu berkaitan erat dengan status gizi anak. Ibu hendaknya memiliki pengetahuan yang baik mengenai asupan gizi bagi balita agar status gizi balita tetap terjaga sehingga terhindar dari masalah-masalah kesehatan di masa yang akan datang.

\section{Referensi}

Adani, V., Pangestuti, D. R., \& Rahfiludin, M. (2016). Hubungan Asupan Makanan (Karbohidrat, Protein dan Lemak) dengan Status Gizi Bayi dan Balita (Studi pada Taman Penitipan Anak Lusendra Kota Semarang Tahun 2016). Jurnal Kesehatan Masyarakat (e-Journal), 261 - 271.

Adriani, M., \& Bambang, W. (2012). Pengantar Gizi Masyarakat. Jakarta: Kencana Prenada Media Group.

Aridiyah, F. O., Rohmawati, N., \& Ririanty, M. (2015, Januari). Faktor-faktor yang Mempengaruhi Kejadian Stunting pada Anak Balita di Wilayah Pedesaan dan Perkotaan. eJurnal Pustaka Kesehatan, 3, 163 - 170.

Arif, N. (2009). ASI dan Tumbuh Kembang Bayi. Jakarta: MedPress.

Arnisam, Salfiyadi, T., \& Lura, L. S. (2013). Hubungan Asupan Mineral Zinc (Seng) dan Vitamin A dengan Kejadian Diare Pada Balita di Kecamatan Seulimeum. Idea Nursing Journal, 66 - 73.

Astutik, Rahfiludin, M., \& Aruben, R. (2018). Faktor Risiko Kejadian Stunting pada Anak Balita Usia24-59 Bulan. Jurnal Kesehatan Masyarakat, 409 - 418.

Baculu, E. P. (2017). Hubungan Pengetahuan Ibu dan Asupan Karbohidrat dengan Status Gizi Pada Anak Balita di Desa Kalangkangan Kecamatan Galang Kabupaten Tolitoli. Promotif, 14 - 17.

Badan Penelitian dan Pengembangan Kesehatan Kementerian Kesehatan RI. (2013). Hasil Rikesdas 2013. Jakarta: Badan Penelitian dan Pengembangan Kesehatan Kementerian Kesehatan RI.

Desfita, S., \& Priwahyuni, Y. (2014). Status Gizi Balita dan Karakteristiknya di Dua Kecematan di Kota Pekan Baru. Gizi Indonesia, 37, 51 - 61.

Dewi, \& Nindya. (2017). Hubungan Tingkat Kecukupan Zat Besi dan Seng dengan Kejadian Stunting pada Balita 6-23 Bulan. Amerta Nutr, 361 - 368.

Dinas Kesehatan Nusa Tenggara Timur. (2015). Profil Kesehatan Provinsi Nusa Tenggara 
Timur Tahun 2015. (E. R. Salmun, D. Hutahaean, A. Kikhau, M. T. Roja, \& Y. D. Rini, Eds.) NTT: Dinas Kesehatan Nusa Tenggara Timur.

Dinas Kesehatan Nusa Tenggara Timur. (2015). Profil Kesehatan Provinsi Nusa Tenggara Timur Tahun 2015. (E. R. Salmun, D. Hutahaean, A. Kikhau, M. T. Roja, \& Y. D. Rini, Penyunt.) NTT: Dinas Kesehatan Nusa Tenggara Timur.

Diniyyah, S. R., \& Nindya, T. S. (2017). Asupan Energi, Protein dan Lemak Dengan Kejadian Gizi Kurang Pada Balita Usia 24-59 Bulan di Desa Suci Gresik. Amerta Nur, 341 - 350.

Gani, I., \& Amalia, S. (2015). Alat Analisis Data: Aplikasi Statistik untuk Penelitian Bidang Ekonomi dan Sosial. Yogyakarta: ANDI.

Hardinsyah, \& Supariasa, I. D. (2016). Ilmu Gizi: Teori dan Aplikasi. Jakarta: EGC.

Helmi, R. (2013, April). Faktor - Faktor yang Berhubungan dengan Status Gizi pada Balita di Wilayah Kerja Puskesmas Margototo Kecematan Metro Kibang Kabupaten Lampung Timur. Jurnal Kesehatan, VI (), 233 -242 .

Ikatan Dokter Anak Indonesia. (2010). Indonesia Menyusui. (R. Suradi, B. Hegar, I. G. Pratiwi, A. N. Marzuki, \& Y. Ananta, Penyunt.) Indonesia: Badan Penerbit IDAI.

International Food Policy Research Institute. (2016). Global Nutrition Report 2016: From Promise to Impact Ending Malnutrition By 2030. Washington, DC.

Jayarni, D. E., \& Sumarmi, S. (2018). Hubungan Ketahanan Pangan dan Karakteristik Keluarga dengan Status Gizi Balita Usia 2 - 5 Tahun. amerta nutr, 44-51.

Kalsum, U., \& Gandini, A. L. (2016). Hubungan Pengetahuan Ibu tentang Pengolahan Makanan dengan Status Gizi Balita. mahakam Nursing Journal, 47-56.

Kementerian Kesehatan Republik Indonesia. (2010). Manajemen Terpadu Balita Sakit (MTBS). Jakarta: Indonesia Sehat.

Kementerian Negara Perencanaan Pembangunan Nasional. (2008). Strategi NAsional Pengembangan anak Usia Dini Holistik Integratif. Jakarta: Bappenas.

Khomsan, A. (2007). Study Implementasi Program Gizi: Pemanfaatan Cakupan Keefektifan dan Dampak terhadap Status Gizi. Bogor:
Departemen Gizi Masyarakat Institut Pertanian Bogor.

Khotimah, H., \& Kuswandi, K. (2014). Hubungan Karakteristik Ibu dengan Status Gizi Balita di Desa Sumur Bandung Kecematan Cikulur Kabupaten Lebak. Jurnal Obstretika Scientia, $146-162$.

Losong, N. H., \& Adriani, M. (2017). Perbedaan Kadar Hemoglobin, Asupan Zat Besi, dan Zinc pada Balita Stunting dan NonStunting. Amerta Nutr, 117 - 123.

Nilakesuma, A., Jurnalis, Y. D., \& Rusjdi, S. R. (2015). Hubungan Status Gizi Bayi dengan Pemberian ASI Ekslusif, Tingkat Pendidikan Ibu dan Status Ekonomi Keluarga di Wilayah Kerja Puskesmas Padang Pasir. Jurnal kesehatan andalas, 37-44.

Oktavianis. (2016). Faktor-Faktor yang Berhubungan dengan Status Gizi pada Balita di Puskesmas Lubuk Kilangan. Journal Human Care, I.

Par'i, H. M. (2016). Penilaian Status Gzi: Dilengkapi Proses Asuhan Gizi Standar. Jakarta: EGC.

Pemerintah Provinsi Banten. (2016, Mei 20). Sustainable Development Goals (SDGs) / Tujuan Pembangunan Berkelanjutan. Retrieved Juni 1, 2017, from http://blhd.bantenprov.go.id/upload

Pos Kupang. (2017, Maret 3). Pemerintah dan Balita Gizi Buruk. Retrieved Mei 4, 2017, from POS Kupang: http://kupang.tribunnews.com/2017/03/03/pe meritah-dan-balita-gizi-buruk

Pos Kupang. (2016, Februari 29). PosKupang.com. Dipetik 10 Juli 2018, dari Pernikahan Usia Dini Bawa Banyak Masalah: http://kupang.tribunnews.com/2016/02/29/pe rnikahan-usia-dini-bawa-banyak-masalahPos Kupang. (2017, Maret 3). Pemerintah dan Balita Gizi Buruk. Dipetik 4 Mei 2017, dari Pos Kupang: Http://Kupang.Tribunnews.Com/2017/03/03/ Pemeritah-Dan-Balita-Gizi-Buruk

Pos Kupang. (2015, November). Pos-Kupang.com. Dipetik 10 Juli 2018, dari Cakupan ASI Ekslusif di Kota Kupang Masih Rendah: http://kupang.tribunnews.com/2015/11/06/ca kupan-asi-eksklusif-di-kota-kupang-masihrendah

Pramana, C. (2018). Hubungan antara Kecukupan Asupan Kalsium dan Zat Besi terhadap Status 
Faletehan Health Journal, 8 (2) (2021) 92-101

Gizi Anak di Sekolah Negeri Pabelan 01 Kartasura [Skripsi]. Surakarta: Universitas Muhammadiyah

Puspasari, N., \& Andriani, M. (2017). Hubungan Pengetahuan Ibu tentang Gizi dan Asupan Makan Balita dengan Status Gizi Balita (BB/U) Usia 12-24 Bulan. Amerta Nutr, 369378.

Putri, R. F., Sulastri, D., \& Lestari, Y. (2015). Faktor - faktor yang berhubungan dengan status Gizi Anak balita di wilayah kerja Puskesmas Nanggalo Padang. Jurnal Kesehatan Andalas, 254 - 261.

Regar, E., \& Sekartini, R. (2013, Desember). Hubungan Kecukupan Asupan Energi dan Makronutrien dengan Status Gizi Anak Usia 5-7 Tahun di Kelurahan Kampung Melayu, Jakarta Timur Tahun 2012. eJKI, 1, 184 - 189.

Rismiati. 2016. Hubungan Asupan Mikronutrien Dan Status Gizi Anak Usia 2-5 Tahun di Wilayah Posyandu Gonilan [Skripsi]. Surakarta (ID): Universitas Muhammadiyah.

Sari, E. M., Juffier, M., Nurani, N., \& Sitaresmi, M. N. (2016, April). Asupan Protein, Kalsium dan Fosfor pada Anak Stunting dan Tidak Stunting Usia 24-59 Bulan. Jurnal Gizi Klinik Indonesia, 12, 152 -159.

Sealey, P., \& AC, P. (2014). An Assessment of Dietary Diversity and Nutritional Status of Preschool Children. Austin J Nutri Food Sci, 1-5.

Sharlin, J., \& Edelstein, S. (2014). Buku Ajar Gizi dalam Daur kehidupan. (C. A. Agustina, E. Rezkina, Q. Rahmah, Penyunt., Y. Kristianto, \& A. O. Tampubolon, Penerj.) Jakarta: EGC.

Sudargo, T., LM, H. F., Rosiyani, F., \& Kusmayanti, N. A. (2014). Pola Makan dan Obesitas. Yogyakarta: Gajah Mada University Press.

Suryani, L. (2017). Faktor Yang Mempengaruhi Status Gizi Balita di Wilayah Kerja Puskesmas Payung Sekaki Pekanbaru. Jomis (Journal of Midwifery Science), 1, 47-53.

Susilo, H. W. (2013). Prinsip-Prinsip Biostatistika dan Aplikasi SPSS pada Ilmu Keperawatan. Jakarta: IN MEDIKA.

Wawan, \& Dewi. (2011). Pengetahuan Sikap dan Perilaku Manusia. Yogyakarta: Nuha Medika.

Wijayanti, N. (2017). Fisiologi Manusia dan Metabolisme Zat Gizi. Malang: Universitas Brawijaya Press (UB Press).
Wiku, A. (2010). Sistem Kesehatan Masyarakat. Jakarta: Rajawali Pers.

Williams, L., \& Wilkins. (2011). Nutrition Made Iincredibly Easy. (A. W. Nugroho, N. Santoso, Penyunt., \& L. Dwijayanthi, Penerj.) Jakarta: EGC.

Ziliwu, N.S.P., Anggraeni, L.D., \& Lina, R.N. (2020). Factors Associated with Nutritional Status of Children Under Five Years Of Age In Gunungsitoli Idanoi Primary Healthcare Center. The Indonesian Journal of Public Health, Vol 15, No 3: 315-324 